\title{
OCCURRENCE OF BRUCELLA IN MILK AND CREAM
}

\author{
A.M. EL-KHOLY ${ }^{1}$; A.M.S. MESHREF ${ }^{1}$; N.A. HAMED ${ }^{2}$ and F.E.A. SALEH ${ }^{2}$ \\ ${ }^{1}$ Food Hygiene Department, Faculty of Veterinary Medicine, Beni-Suef University \\ ${ }^{2}$ Animal Health Research Institute, Egypt
}

Received: 28 September 2017; $\quad$ Accepted: 12 October 2017

\begin{abstract}
A total of 200 samples (100 Farmer raw cow's milk, 60 market milk and 40 fresh cream) were collected from individual farmers, different dairy shops and milk separation centers distributed through Beni-Seuf and El-Minia cities, Egypt. The milk samples were subjected to serological test for detection of Brucella antibodies, using Milk ring test (MRT), Whey Buffered acidified plate antigen test (wBAPAT) and Whey Rose Bengal plate test (wRBPT). Out of 100 farmers milk samples examined by MRT. 30\%, 7\% and 63\% were positive, suspicious and negative respectively. Also, $44 \%$ and $42 \%$ of these samples were positive for wBAPAT and wRBPT, respectively. On the other hand, Out of 60 market milk samples examined by MRT. 23.3\%, 8.4\% and $68.3 \%$ were positive, suspicious and negative, respectively, while $53.4 \%$ and $48.4 \%$ were positive for wBAPAT and wRBPT, respectively. All samples were examined bacteriologically for presence of Brucella organisms. The prevalence of Brucella species in farmers milk, market milk and cream samples were 28\%, 60\% and $32.5 \%$, respectively. All isolates were typed as Brucella melitensis biovar 3. The public health significance and suggestive control measures were discussed.
\end{abstract}

Key words: Brucella, Milk, Cream, Brucella antibodies.

\section{INTRODUCTION}

In Egypt, direct consumption of raw milk is more frequent and more popular than the pasteurized one because it's believed, especially in rural areas, that the raw milk and its byproducts have nutritional advantages over the pasteurized one. Furthermore, milk is produced mainly by individual in small farms that lack proper sanitary measures and may be either consumed fresh, manufactured into dairy products or sell in retail markets that alarming as a major source of food borne brucellosis (El-Sayed et al., 2011) and represent a serious human health problem.

Brucella is excreted in milk, it attains $10 \% / \mathrm{ml}$ at the beginning of the lactation and then it decline to $10 / \mathrm{ml}$ but may persist during successive lactation periods (Plommet et al., 1988). The Food and Agriculture Organization (FAO), the World Health Organization (WHO) and the Office International des Epizooties (OIE) considered Brucellosis as one of the widest spread zoonotic diseases of domestic and wild animals throughout the world (Schelling et al., 2003 and Thakur et al., 2002). The World Health Organization (WHO) recently estimated that the median global number of cases of foodborne illness

Corresponding author: Dr. F.E.A. SALEH

E-mail address: fateneid2290@ gmail.com

Present address: Animal Health Research Institute, Egypt due to Brucella infection was 393,239 (Havelaar et al., 2015). The main pathogenic species in both animals and human are Brucella melitensis, Brucella abortus, Brucella suis, and Brucella canis (Cloeckaert and Vizcaino, 2004 and Araj, 2010), while Brucella melitensis is currently the predominant species of Brucella present in Egypt (Holt et al., 2011) precisely Brucella melitensis biovar 3 is the most common isolate of Brucella in Egypt (Refai, 2002 and Samaha et al., 2007).

Brucellosis was first reported in Egypt in 1939 and is now considered endemic in most parts of the country (Refai, 2002 and Molina-Flores, 2010), it appear to be of particular risk in rural communities especially in Upper Egypt (Molina-Flores, 2010). Despite its economic and public health importance, the official Egyptian brucellosis control program does not appear to have been fully implemented (Refai, 2002 and Hegazy et al., 2009).

The presence of Brucella organism in milk has conducted by several investigators (Abdel-Hakiem, 1999; Abd-Alla et al., 2000; Meshref, 2000; AbdelAll, 2001; El- Sayed et al., 2011; Abd Al-Azeem et al. (2012); Abosira 2015 and El-Diasty et al., 2016).

Diagnosis of Brucellosis is the corner stone of proper eradication of the disease. Isolation of the causative agent is still the land mark for diagnosis of brucellosis (Alton et al., 1988), however; it is 
difficult to recover from life infected animals, therefore diagnosis has been based mostly on the results of serological tests (Hamdy, 1997). It is easier for using milk and milk whey for diagnosing brucellosis as injuring animals for collecting blood samples is difficult (Farag, 1998).

There is limited recent data on the prevalence of Brucella organisms in the Upper Egypt. Therefore, the present work was planned to investigate the incidence of Brucella organisms in milk and fresh cream and to throw the light upon the public health significance and preventive and control measures of brucellosis.

\section{MATERIALS AND METHODS}

1-Collection of samples:

A total of 200 random samples including Farmers milk (100 raw cow's milk samples were collected from individual farmers in Beni-Seuf and El-Minia cities), Market milk (60 samples were collected from different retail shops and vendors in Beni-Suef and El-Miniacities, Egypt) and Cream (40 samples from the separators in Beni-Seuf and El-Minia cities). All samples were collected in sterilized bottles and transported to the laboratory in an insulated ice box $\left(4-6^{\circ} \mathrm{C}\right)$ and kept in the refrigerator till be examined.

\section{2- Serological examination:}

Milk whey samples were prepared according to (Morgan et al., 1978). The assigned tests were carried out on the samples as follow:

2.1. Milk Ring Test (Alton et al., 1988).

2.2. Whey Buffered Acidified Plate Antigen Test (wBAPAT) (Alton et al., 1988).

2.2. Whey Rose Bengal Plate Test (wRBPT) (Alton et al., 1988).

\section{3- Isolation and identification of Brucella organisms:}

\subsection{Direct culture method:}

Briefly, the milk sample was centrifuged at $3000 \mathrm{rpm}$ for 10 minutes to obtain the sediment-creammixture (Alton et al., 1988) which then was cultured on duplicated plates of serum dextrose agar plates containing Brucella selective antibiotics (Oxoid code: SR0083, Hampshire, UK). The plates were incubated in presence of $5-10 \% \mathrm{CO}_{2}$ and aerobically at $37{ }^{\circ} \mathrm{C}$ for up to 2 weeks. The plates examined every 2 days for any Brucella growth.

\subsection{Indirect cultural method (Brodie and Sinton, 7. 1975):}

Two $\mathrm{ml}$ of fresh cream were inoculated into bottles (50 ml volume) of serum dextrose broth containing Brucella selective supplements (Oxoid code: SR0083, Hampshire, UK), then incubated at $37{ }^{\circ} \mathrm{C}$ in carbon dioxide incubator (5-10\% tensions) for 3-5 days. The broth was the sub-cultured onto selective serum dextrose agar plates and the plates as well as control ones were incubated at $37{ }^{\circ} \mathrm{C}$ in carbon dioxide incubator (5-10\% tensions) for 3-5 days. The plates examined every 2 days for any Brucella growth.

All of the isolates were subjected to standard morphological and biochemical tests, including morphological characters of the colonies, microscopical appearance, $\mathrm{CO} 2$ requirement, growth in the presence thionin and basic fuschin dyes, and agglutination with Brucella anti-sera A and M.

\section{4- Molecular examination of Brucella:}

\subsection{Extraction of DNA for PCR assay:}

DNA was extracted from colonies by using QIA amp DNA Mini Kit Catalogue no.51304. It provides silica-membrane-based nucleic acid purification from different types of samples.

\subsection{DNA amplification:}

Conventional PCR (Bricker, 2002) was carried out for identification of the DNA extracts to confirm the presence of genetic material of genus Brucella. Amplification of target gene (Immunodominant antigen, gene bp26) was carried out in a final volume of $25 \mu \mathrm{l}$ in containing $\left(12.5 \mu \mathrm{lBiomatik}{ }^{\circledR}\right.$ master mix, $1 \mu \mathrm{l}$ forward primer, $1 \mu \mathrm{l}$ reverse primer, $7.5 \mu \mathrm{l}$ nuclease free water and $3 \mu \mathrm{l}$ DNA template. The amplification was performed in Labnet ${ }^{\circledR}$ Multigen Gradient thermal cycler, Catalog TC9600-G- 230V. (Labnet international, Inc. Edison, NJ, USA).

Cycling conditions of the different primers during CPCR

\begin{tabular}{ccccccc}
\hline Gene & $\begin{array}{c}\text { Primary } \\
\text { denaturation }\end{array}$ & $\begin{array}{c}\text { Secondary } \\
\text { denaturation }\end{array}$ & Annealing & Extension & $\begin{array}{c}\text { No. of } \\
\text { cycles }\end{array}$ & $\begin{array}{c}\text { Final } \\
\text { extension }\end{array}$ \\
\hline Immunodominant & $95^{\circ} \mathrm{C}$ & $94^{\circ} \mathrm{C}$ & $60^{\circ} \mathrm{C}$ & $72^{\circ} \mathrm{C}$ & 35 & $72^{\circ} \mathrm{C}$ \\
antigen, gene $b p 26$ & $4 \mathrm{~min}$. & $45 \mathrm{sec}$. & $45 \mathrm{sec}$. & $60 \mathrm{sec}$. & $7 \mathrm{~min}$. \\
\hline
\end{tabular}


Oligonucleotide primers sequences.

\begin{tabular}{ccccc}
\hline Primer & Sequence (5'-3') & $\begin{array}{c}\text { Amplicon } \\
\text { size (bp) }\end{array}$ & DNA targets & $\begin{array}{c}\text { Source of genetic } \\
\text { Difference }\end{array}$ \\
\hline BMEI0535f & $\begin{array}{c}\text { GCG-CAT-TCT-TCG- } \\
\text { GTT-ATG-AA }\end{array}$ & 450 & $\begin{array}{c}\text { Immunodominant } \\
\text { antigen, } \\
\text { gene bp26 }\end{array}$ & $\begin{array}{c}\text { IS711 insertion in } \\
\text { BMEI0535-BMEI0536 } \\
\text { BMEI0535r Brucella strains isolated } \\
\text { from marine mammals }\end{array}$ \\
\hline
\end{tabular}

4.3 Detection and identification of PCR product.

The PCR products were detected through $1.5 \%$ agarose gel stained with ethidium bromide solution $(0.5 \mu \mathrm{g} / \mathrm{ml})$ and visualized under an ultraviolet trans-illuminator and photographed.

\section{RESULTS}

Table 1: Incidence of Brucella organisms in the milk sample based on MRT.

\begin{tabular}{|c|c|c|c|c|c|c|c|}
\hline \multirow{3}{*}{ Type of Samples } & \multirow{3}{*}{ No. of Samples } & \multicolumn{6}{|c|}{ MRT } \\
\hline & & \multicolumn{2}{|c|}{+} & \multicolumn{2}{|c|}{ \pm} & \multicolumn{2}{|c|}{-} \\
\hline & & No. & $\%$ & No. & $\%$ & No. & $\%$ \\
\hline Farmers Milk & 100 & 30 & 30 & 7 & 7 & 63 & 63 \\
\hline Market Milk & 60 & 14 & 23.3 & 5 & 8.4 & 41 & 68.3 \\
\hline Total & 160 & 44 & 27.5 & 12 & 7.5 & 104 & 65 \\
\hline
\end{tabular}

$\%$

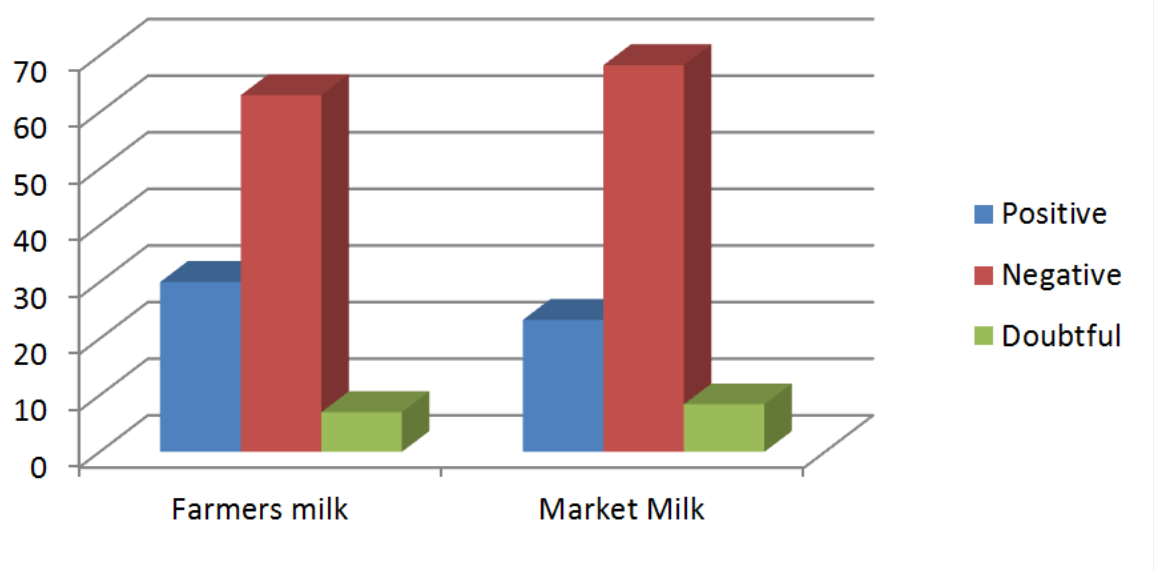

Figure 1: Incidence of Brucella organisms in the farmers and market milk based on the results of MRT.

Table 2: Incidence of Brucella organisms in the milk samples based on wBAPAT.

\begin{tabular}{|c|c|c|c|c|c|}
\hline \multirow{3}{*}{ Type of Samples } & \multirow{3}{*}{ No. of Samples } & \multicolumn{4}{|c|}{ wBAPAT } \\
\hline & & \multicolumn{2}{|c|}{+} & \multicolumn{2}{|c|}{-} \\
\hline & & No. & $\%$ & No. & $\%$ \\
\hline Farmers Milk & 100 & 44 & 44 & 56 & 56 \\
\hline Market Milk & 60 & 32 & 53.3 & 28 & 46.7 \\
\hline Total & 160 & 76 & 47.5 & 84 & 52.5 \\
\hline
\end{tabular}




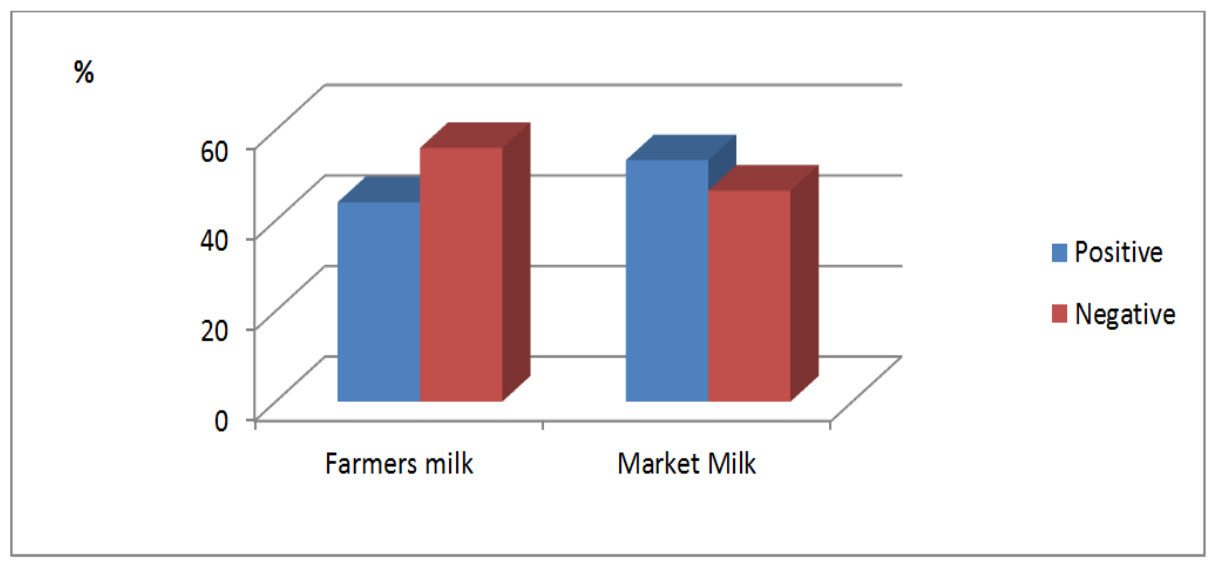

Figure 2: Incidence of Brucella organism in the farmers and market milk based on the results of wBAPAT.

Table 3: Incidence of Brucella organisms in the milk samples based on wRBPT.

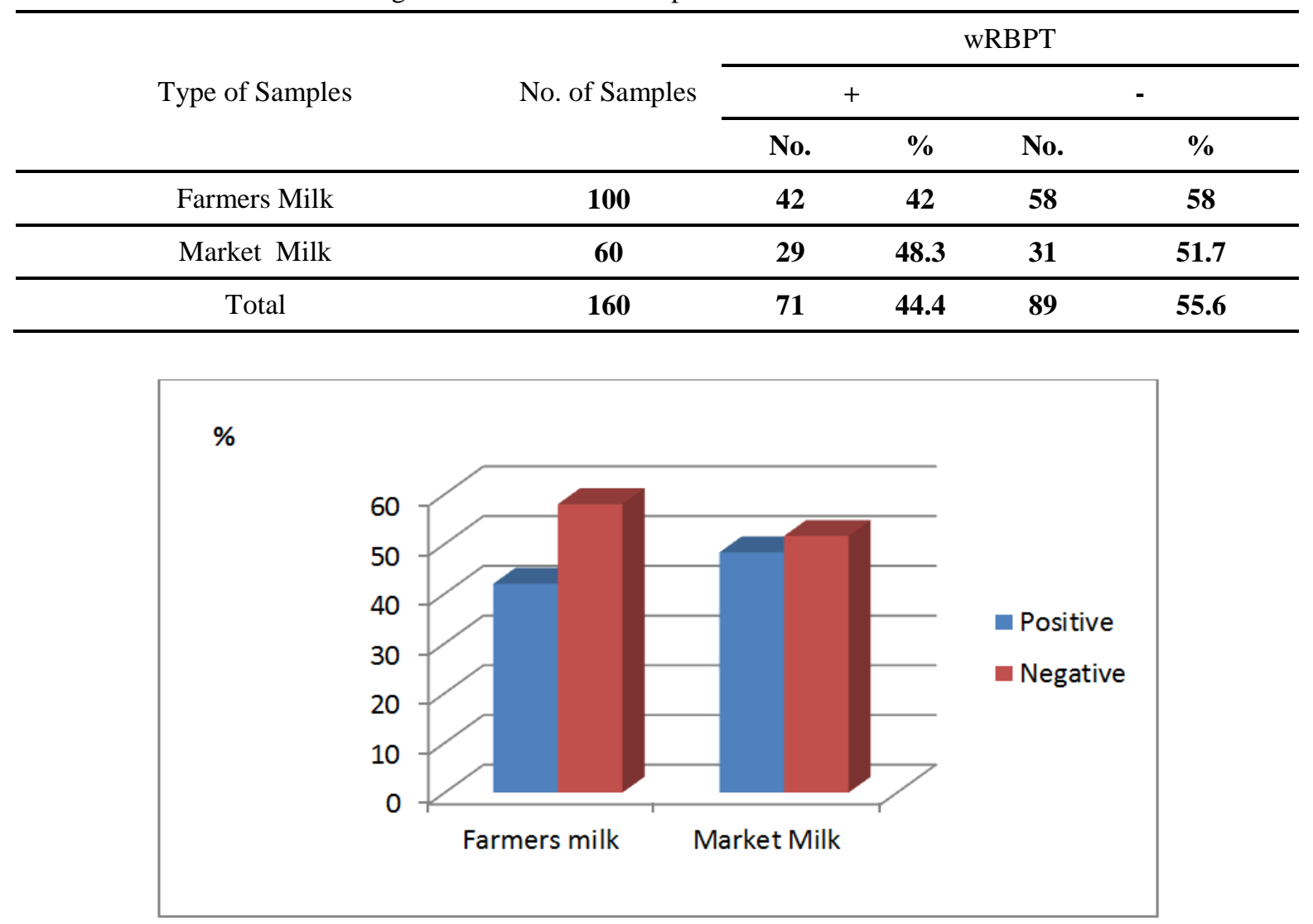

Figure 3: Incidence of Brucella organisms in the farmers and market milk based on the results of wRBPT.

Table 4: Isolation of Brucella organisms from the milk and fresh cream.

\begin{tabular}{cccc}
\hline \multirow{2}{*}{ Type of samples } & No. of Samples & \multicolumn{2}{c}{ Positive Samples } \\
\cline { 3 - 4 } & & No. & $\mathbf{2 8}$ \\
\hline Farmers milk & $\mathbf{1 0 0}$ & $\mathbf{2 8}$ & $\mathbf{6 0}$ \\
\hline Market milk & $\mathbf{6 0}$ & $\mathbf{3 6}$ & $\mathbf{3 2 . 5}$ \\
\hline Fresh Cream & $\mathbf{4 0}$ & $\mathbf{1 3}$ & $\mathbf{3 8 . 5}$ \\
\hline Total & $\mathbf{2 0 0}$ & $\mathbf{7 7}$ &
\end{tabular}




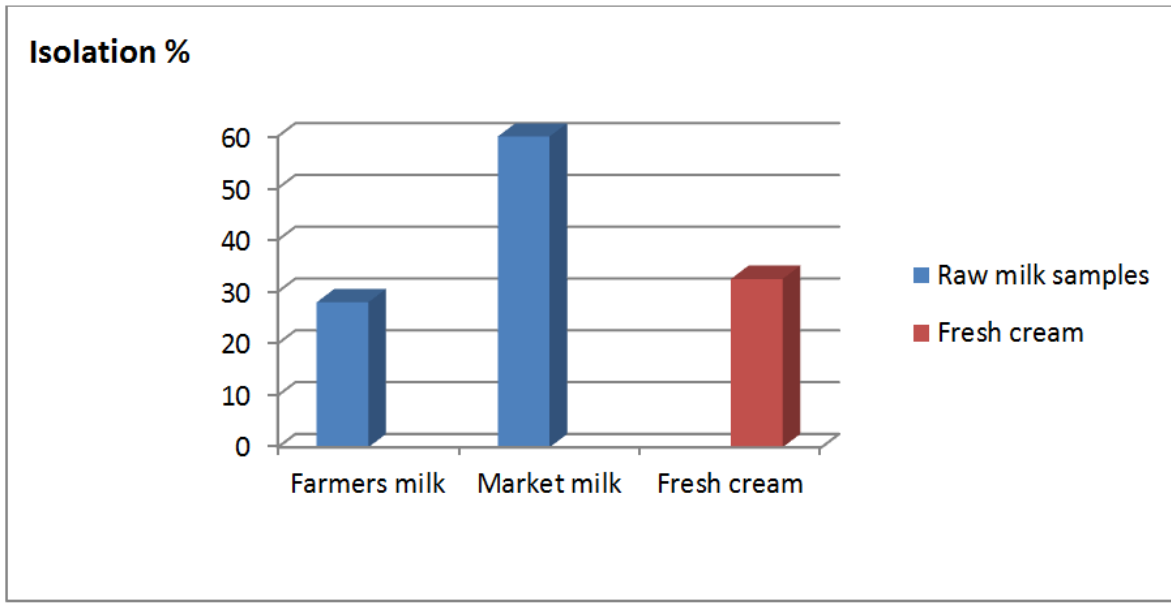

Figure 4: Isolation of Brucella organisms from the milk and fresh cream.

Table 5: Identification of isolated strains.

\begin{tabular}{|c|c|c|c|c|c|c|}
\hline \multirow[t]{2}{*}{ Strain } & \multicolumn{2}{|c|}{$\begin{array}{c}\text { Farmers Milk } \\
(100)\end{array}$} & \multicolumn{2}{|c|}{$\begin{array}{l}\text { Market milk } \\
(60)\end{array}$} & \multicolumn{2}{|c|}{$\begin{array}{c}\text { Cream } \\
(40)\end{array}$} \\
\hline & No. & $\%$ & No. & $\%$ & No. & $\%$ \\
\hline $\begin{array}{c}\text { Br. melitensis } \\
\text { biovar } 3\end{array}$ & 28 & 28 & 36 & 60 & 13 & 32.5 \\
\hline Br. abortus & - & - & - & - & - & - \\
\hline Br. suis & - & - & - & - & - & - \\
\hline
\end{tabular}

Conventional PCR for detection of Brucella DNA on genus level

$\begin{array}{lllllllll}1 & 2 & 3 & 4 & 5 & 6 & 7 & 8\end{array}$

Lane 1:DNA ladder

Lane 2-6, 9: positive sample for Brucella

Lane 7-8: negative

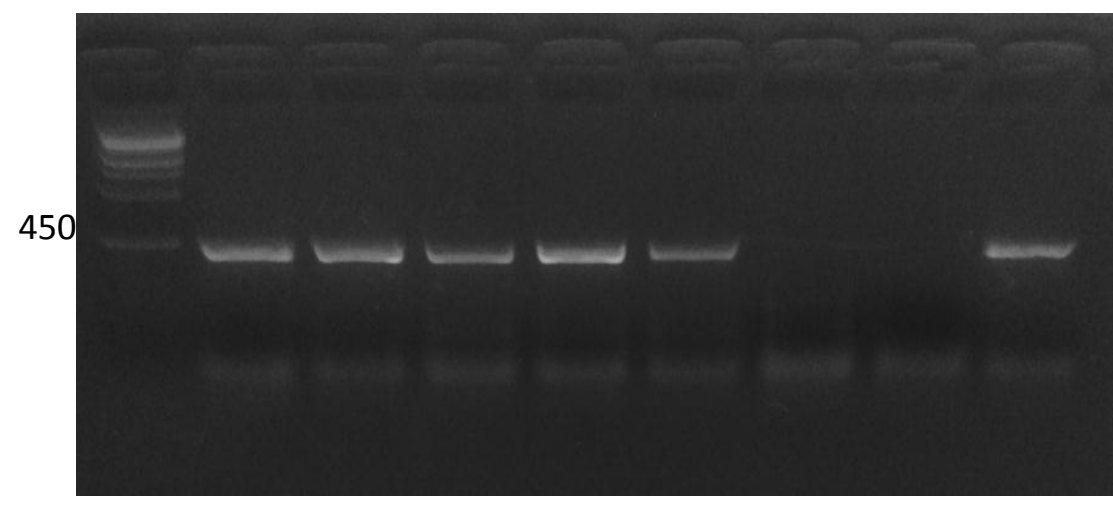

Lane 1:100 bp DNA ladder Lane 2-6: positive sample for Brucella

Lane 7: negative

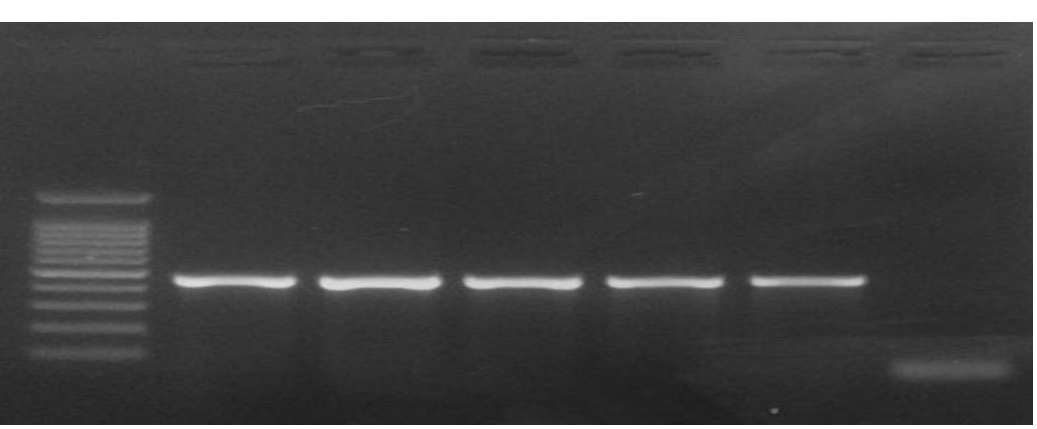

Figure5: Gel electrophoresis of PCR products using universal primer set (with 450 bp expected product size). 


\section{DISCUSSION}

Data presented in Table (1) and Figure (1) showed the incidence of Brucella antibodies in the examined raw milk based on the milk ring test (MRT).Out of 100 Farmers milk samples, $30(30 \%)$ were positive, 7 $(7 \%)$ were suspicious and $63(63 \%)$ were negative.

This positive result agreed with those recorded by Abosria (2015) and nearly simulated to the finding recorded by El-Gibaly et al. (1995) and Miller et al. (2015) which were $28.2 \%$ and $28.7 \%$ respectively, while the gained result was higher than those obtained by Mohamed (1989), Zowghi et al. (1990), Hosein and El-Kholy (1993), Kadry (1996), AbdelHakiem (1999), El-Sherbini et al. (2002), Shehata (2004), Abd El Hamid (2008), El-Kholy et al. (2008), Shafee et al. (2011) and Ali et al. (2014), whom reported incidences of $22.25 \%, 25.2 \%, 4.1 \%$, $0.99 \%, 8 \%, 10 \%, 12.38 \%, 14.7 \%, 8.2 \%, 4.6 \%$, and $6.7 \%$ respectively.

The relatively high results obtained by using MRT could be attributed to the fact that MRT is highly sensitive, rapid screening test (Ferguson and Rebortson, 1954; El Gibaly, 1969 and Salem et al., 1987).

On the other hand, it was relatively lower than those reported by Meshref (2000), Abd El-All (2001), Hamdy and Amin (2002), Ibrahim et al. (2002), Hashim et al. (2007), El-Diasty (2009), Abdalla and Hamid (2011), El-Sayed et al. (2011), Ibrahim et al. (2012) and Al-Mariri (2015) whom found incidence of $73.68 \%, 38.33 \%, 48.1 \%, 48 \%, 80 \%, 74 \%, 36.7 \%$, $60.2 \%, 47.8 \%$ and $57 \%$, respectively.

Despite MRT was recommended by (FAO/WHO, 1986) as surveillance test for detection of Brucella in milk due to its economical and practical advantages, the major limitations of the test are mastitis milk, skimmed milk, colostral, the dilution factors as well as milk agglutinations are locally produced in the udder of the infected cases and clustering of fat globules or low level of $\operatorname{IgA}$ and $\operatorname{IgM}$ tend to yield false negative results (Corbel et al., 1984).

On the other hand the result illustrated in Table (1) and Figure (1) revealed that out of 60 market milk samples, $14(23.3 \%)$ were positive, $5(8.4 \%)$ were suspicious and $41(68.3 \%)$ were negative.

Our result was higher than those recorded by Kang'ethe et al. (2004), Bertu et al. (2010) and Ior and Chukwu (2015), whom reported that 3.9\%, $12 \%$ and $12.5 \%$ of their samples, were positive respectively. In the contrary, Abd El Hamid (2008) reported that all market milk samples were negative to MRT.
Concerning whey buffered acidified plate antigen test, the recorded results in Table (2) and Figure (2) showed that the incidence of Brucella antibodies in the examined whey. Out of 100 Farmers milk samples, $44(44 \%)$ were positive and $56(56 \%)$ were negative. Also, out of 60 market milk samples, 32 $(53.3 \%)$ were positive and 28 (46.7\%) were negative.

Many reports dealing with prevalence of Brucella in milk have been accumulated. In those studies, various rates of prevalence were reported as $38.9 \%$, $54.9 \%, 50 \%, 4.29 \%, 6.67 \%, 2.4 \%, 20.6 \%, 14.1 \%$, $56 \%$ and $78.1 \%$ were obtained by Abdel-Rahman (1991), Hamdy (1997), Meshref (2000), El-Bassiony et al. (2007), Omran (2007); Oraby et al. (2007), Abdel-Hamid (2008) and El-Kholy et al. (2008), ElDiasty (2009) and Abd Al-Azeem et al. (2012) respectively.

The obtained results in Table (3) and Figure (3) showed that the incidence of Brucella antibodies in the examined whey samples based on the result of whey Rose Bengal plate agglutination test. Out of 100 Farmers milk samples, $42(42 \%)$ were positive and $58(58 \%)$ were negative. On the other hand, in case of market milk, out of 60 examined samples, 29 $(48.4 \%)$ were positive and $31(51.6 \%)$ were negative.

Lower results were detected by Abdel-Rahman (1991), Hamdy (1997), Abd-Alla et al. (2000), ElBassiony et al. (2007), Omran (2007), Oraby et al. (2007), Abdel Hamid (2008) and El- Kholy et al. (2008) where as they reported $22.1 \%, 39.2,3.53$, $4.29 \%, 6.67 \%, 2.4 \%, 15.7 \%$ and $11.8 \%$ respectively, but a nearly similar result (44\%) was detected by Meshref (2000) and El- Diasty (2009), while higher value $(75 \%)$ was recorded byAbd Al-Azeem et al. (2012)

The difference in the incidence rate might be due to the variation of the degree of infection, also the appearance of antibody is related to many factors such as size and method of exposure, virulence of organism, stage of pregnancy and previous exposure. The antibody titer usually reach diagnostic level by four weeks after exposure during fourth to sixth month of gestation and at 10 weeks after exposure in non-pregnant or in the first trimester gestation (Nicoletti, 1990). The high results may be correlated with high prevalence in unknown history of animals which might be due to lack of appropriate diagnostic facility at field level and screening of animals for brucellosis prior to purchase.

The result obtained in Table (4) and Figure (4) revealed that $28(28 \%)$ out of 100 Farmers milk samples were found to be contaminated with Brucella organisms. This finding was nearly similar to the result $(28.57 \%)$ that was reported by Abosria (2015), while higher prevalence $(40.6 \%)$ was recorded by Abd Al-Azeem et al. (2012) and (33.8\%) 
was recorded by Ibrahim et al. (2012), but lower prevalence $(7.5 \%)$ was recorded by Abd-Alla and Hamid (2011) and (4\%) by Abdel-Kareem et al. (2011).

On the other hand the summarized result in Table (4) and Figure (4) revealed that $36(60 \%)$ out of 60 market milk samples were found to be contaminated with Brucella organisms which was much higher than that reported by Meshref (2000) and AbdelHamid (2008) who failed to isolate any Brucella organisms from market milk.

The higher percent in farmers milk may be attributed to the lack of proper sanitary measures under which milk is produced as well as, the high incidence of Brucella infection in the dairy cows. Moreover, higher prevalence in market milk may attributed to the fact that the milk collected from different sources blended before the selling, and explained by the fact that the majority of milk sales are in the hands of farmers who are known to harbor beliefs that milk is inherently hygienic and less likely to get concerned about the hygiene and conservation of milk before sale. (All the collected samples were from bulk milk from various herds and milk sellers each represent). The infected animals serve as sources of infection to healthy animals within the herds as well as other neighboring herds as the animals graze around unrestricted area, making contact between different herds possible, it was understood that most of the milk sold do not undergo any form of heat treatment such as pasteurization or boiling. The recovery of Brucella from milk samples is of great public health significance and presents a particularly serious hazard as previously reported by El-Sayed et al. (2011).

MRT showed lower incidence rate $(23.3 \%)$ in market milk when compared to that recorded by culture method $(60 \%)$ and that may attributed to the dilution factor as the milk from different sources may be blended before selling. On the other hand, MRT showed higher incidence rate in farmers milk $(30 \%)$ when compared to that recorded by culture method (28\%) and that may attributed to the intermittent secretion of Brucella in milk (El-Berg, 1981).

As presented in Table (4) and Figure (4) Brucella organisms were detected in $13(32.5 \%)$ out of 40 fresh cream samples. The obtained result was nearly similar to those reported by Meshref (2000) who found that $(33.3 \%)$ of the cream samples were contaminated. The higher incidence could be attributed to the fact that the cream is usually more heavily infected than whole milk as the Brucella organisms tend to adhere to the surface of fat globules forming a complex which rise to top of milk by means of specific gravity (Champneyz, 1953). In addition, the samples were collected randomly from general separators, which separate the milk of at least
50 small herds/day. Small amounts of milk remains in the separator after each herd are considered as a good mechanical transmitter for pathogenic organisms including Brucella organisms to the following milk. Moreover, poor sanitary measures of the separator whereas washing and sanitation of the separator was done only once/day at the end of day work without using any sterilizer acts as main predisposing factor in mechanical transmission of Brucella organisms from infected to non-infected milk through the separators (Meshref, 2000).

All the obtained isolates from milk and cream were typed as Brucella melitensis biovar 3 as illustrated in Table (5). Isolation of Brucella melitensis biovar 3 from milk was reported by Meshref (2000), Abd Elall et al. (2001), Montasser et al. (2002), Shalaby et al. (2003), Zahran (2004), Abdel Wahab (2005), ElDiasty (2009), Moawad et al. (2013) and Abosria (2015). It is evident that Brucella melitensis biovar 3 is still the prevalent one among cattle in Egypt, also Brucella melitensis is considered the indigenous strain prevalent in sheep and goats in Egypt (El Gibaly et al., 1993 and El- Sheery, 1993). Cattle are readily infected with brucellosis when they are in close contact with infected goats and sheep on communal grazing or at watering (Hellstrom, 1991).

\section{CONCLUSION}

Results of the study clearly indicate that the milk and fresh cream in both examined cities play a dangerous role in transmitting infection to man, so efficient boiling or pasteurization of milk before consumption or processing especially in infected areas to safeguard the consumers should be done. Urgent need for effective program for the control of this disease in reservoir animals in Egypt and educational programs to those sharing in milk production and handling as well as processing of dairy products and at risk population should be encouraged. Further studies on brucellosis should be conducted in other areas for setting up priorities for control measures.

\section{REFERENCES}

Abd Al-Azeem, M.W.; L.M., E.; Zain El Abdein, A.E. and Sayed, H.H. (2012): Molecular and serological studies on detection of Brucella species in Cattles and Buffaloes. J. Pharm. Biomed Sci. 2, 16-24.

Abd El Hamid, R.F. (2008): Studies on Brucella in milk and some milk products in Assuit city. M.V.Sc. Thesis, Fac. Med., Assuit Univ., Egypt.

Abd El-All, A.A. (2001): Prevalence of Brucella organisms in milk and some dairy products. Ph.D., Thesis, Fac. Vet. Med., Cairo University, Giza, Egypt. 
Abd-Alla, A. and Hamid, M.E. (2011): Comparison of conventional and non-conventional techniques for the diagnosis of bovine brucellosis in Sudan. Trop. Anim. Health Prod. 44, 1151-1155.

Abd-Alla, M.M.; Mousad, A.A. and Mountaser, A.M. (2000): Incidence and characterization of brucella microorganisms in raw milk and Kariesh Cheese. Beni-Seuf Vet. Med. J., 10 (1); 41-49.

Abdel-Kareem, A.A.; Ikis, S. and Ak, S. (2011): Comparative investigation on the presence of Brucella spp. in milk of cattle raised in Trakya district by Bacteriological and molecular methods. Veteriner Fakultesi Dergisi (Istanbul); 37(1): 23-33.

Abdel Wahab, L.M.A. (2005): Public health importance of brucellosis in El-Menofiya governorate. Ph.D. Thesis. Fac. Vet. Med. Cairo Univ., Egypt.

Abdel-Hakiem, E.H. (1999): The role of cow's raw milk in transmission of Brucellosis. J. Agriculture in the Tropics and Subtropics, 69: 33-41.

Abdel-Rahman, M.A. (1991): Some epidemiological aspects of bovine brucellosis. M.V.Sc. Thesis. Fac. Vet. Med., Cairo Univ. Egypt.

Abosria, K.H. (2015): Molecular epidemiological investigation on brucella infection in ruminants. M.V.Sc. Thesis. Fac. Vet. Med., Beni-Seuf University.

Ali, S.; Ali, Q.; Melzer, F.; Khan, I.; Akhter, S.; Neubauer, H. and Jamal, S.M. (2014): Isolation and identification of bovine Brucella isolates from Pakistan by biochemical tests and PCR. Trop. Ani. Health Prod. 46(1):73-78.

Al-Mariri, A. (2015): Isolation of Brucellamelitensis strains from Syrian bovine milk samples. Bulg. J. Vet. Med., 18, No 1, 40-48.

Alton, G.G.; Jones, L.M.; Angus, R.D. and Verger, J.M. (1988): Techniques for the Brucellosis Laboratory Institute national De Le Recherche Agronomique. (INRA) Publications, Paris, France.

Araj, G.F. (2010): Update on laboratory diagnosis of human brucellosis. Int J. Antimicrob Agents 2010; 36S:S12-7.

Bertu, W.J.; Dapar, M.; Gusi, A.M.; Ngulukun, S.S.; Leo, S. and Jwander, L.D. (2010): Prevalence of brucella antibodies in marketed milk in Jos and environs. African Journal of Food Science, Vol. 4(2) pp. 062-064.

Bricker, B.J. (2002): PCR as a diagnostic tool for brucellosis. Veterinary microbiology. 90, 435446.

Brodie, J. and Sinton, G. (1975): Br. abortus recovery from milk samples. Health-Bulletin, UK. 30:1, 10-12.
Champneyz, W.D. (1953): Brucella infection in man and animals in Great Britain. Epidemiology and the future. Vet. Rec. 65, 7, 99-104.

Cloeckaert, A. and Vizcaino, N. (2004): DNA polymorphism and taxonomy of Brucella species. In: Lopez-Goni I, Moriyon I, editors. Brucella molecular and cellular biology Horizon bioscience; 2004.p.1-24.

Corbel, M.J.; Stuart, F.A. and Brewer, R.A. (1984): Observations on serological cross-reactions between smooth Brucella spp. and organisms of other genera. Dev. Biol. Stand., 56, 341.

El-Berg, S.S. (1981): A guide to diagnosis, treatment and prevention of human brucellosis. WHO, VPH/ 81, 31, Rev.I.

El-Bassiony, T.; El-Prince, E.; Zein El-Abdeen, S. and Sadek, O.A. (2007): Diagnosis of Brucella infection in dairy cattle with serological tests in Assuit Governorate. Assuit Vet. Med. J., 53: 114, 167-180.

El-Diasty, M.M. (2009): Studies on causes of maintenance of Brucella infection among animals in Egypt. Ph.D. Thesis, Fac. Vet. Med., Beni-Seuf, Cairo Univ., Egypt.

El-Diasty, M.M.; Ahmed, H.A.; Sayour, A.E.; El Hofy, F.I.; Tahoun, A.B. and Shafik, S.M. (2016): Seroprevalence of Brucella spp. in Cattle, Molecular Characterization in Milk, and the Analysis of Associated Risk Factors with Seroprevalence in Humans, Egypt. Vector Borne Zoonotic Dis. 2016 Dec; 16 (12): 758-764.

El-Gibaly, S.M. (1993): Correlation between serotests and isolation of Brucellamelitensis in an infected sheep farm. Proceedings of the Second Scientific Congress Egyptian Society for Cattle Diseases: Volume 1-5-7 December 1993 Assuit Egypt: 195-203.

El-Gibaly, S.M. (1969): Studies on Brucellosis in dairy animals in U.A.R. M. D. thesis, Fac. Vet. Med. Cairo Univ.

El-Gibaly, S.M.; Moussa, A.A.; Kopec, J.D.; Ibrahim, S.I.; Ali, H.S. and Hamdy, M.E.R. (1995): The status of Br. melitensis infected herd with a history of repeated doses of two dead Brucella vaccines. J. Egypt. Vet. Med. Assoc. 55(1\&2), 231-241.

El-Kholy, A.M.; Meshref, A.M.S. and Hassan, G.M. (2008): Sero-diagnosis of brucellosis in cows by using milk. Assuit Vet. Med. J., 54 (117): 107-115.

El-Sayed, M.E.M.; El-Newishy, A.M.A.; Hussein, M.H.; EL-Ged, A.M.S.; El-Basionny, A.A. and El-Olamy, G.M. (2011): Public hazard of Brucella microorganisms in milk and dairy products and survival of Brucella melitensis biovar 3 in old Cheese. Benha Veterinary Medical Journal-Special Issue: 35-41.

El-Sheery, M.N.S. (1993): Some studies on relationship betweem Brucellosis and other 
affection in farm animals. Ph.D. Thesis, Fac. Vet. Med. Seuz canal Univ.

El-Sherbini, M.; Abd El-Khalek, A. and El-Gaml, A. (2002): Evaluation of PCR for detection of Brucella in lactating cows. $6^{\text {th }}$ Vet Med. Zag. Conference (7-9 Sept. 2002) Hurghada. (239249).

FAO/WHO (1986): Sixth report of the joint FAO/WHO Expert Committee on brucellosis. World Health Organization, Geneva, Switzerland.

Farag, H.F. (1998): Screening and confirmatory methods for detection of Brucellosis in milk of some dairy animals in Behara province. M.V.Sc. Thesis, Fac. Vet. Med. Alexandria Univ. Egypt.

Ferguson, G.S. and Robertson, A. (1954): The use of milk ring test in a survey of the incidence of bovine Brucellosis in southern Scotland. J. Hyg.. (Camb.), 52: 24-36.

Hamdy, M.E. (1997): Correlation between humeral and cellular immune response in dairy cows naturally infected with Br. abortus. J. Egypt. Vet. Med. Assoc., 57:1, 331-349.

Hamdy, M.E.R. and Amin, A.S. (2002): Detection of Brucella Species in the Milk of Infected Cattle, Sheep, Goats and Camels by PCR. The Veterinary Journal 2002, 163, 299-305.

Hashim, N.; Hassabo, A. and Yagoub, S.O. (2007): Serological Detection of Brucellosis in Cattle and Human. Research Journal of Microbiology, 2: 861-865.

Havelaar, A.H.; Kirk, M.D.; Torgerson, P.R.; Gibb, H.J.; Hald, T.; Lake, R.J.; Praet, N.; Bellinger, D.C.; de Silva, N.R.; Gargouri, N.; Speybroeck, N.; Cawthorne, A.; Mathers, C.; Stein, C.; Angulo, F.J. and Devleesschauwer, B. (2015): World Health Organization Foodborne Disease Burden Epidemiology Reference, G., 2015. World Health Organization global estimates and regional comparisons of the burden of foodborne disease in 2010, PLoS medicine, 12, e1001923.

Hegazy, Y.M.; Ridler, A.L. and Guitian, F.J. (2009): Assessment and simulation of the implementation of brucellosis control programme in an endemic area of the Middle East. Epidemiol. Infect. 2009, 137(10): 14361448.

Hellstorm, J.S. (1991): New Zealand is free from Bovine Brucellosis. Surveillance., 18(1):14

Holt, H.R.; Eltholth, M.M.; Hegazy, Y.M.; El-Tras, W.F.; Tayel, A.A. and Guitian, J. (2011): Brucella spp. infection in large ruminants in an endemic area of Egypt: cross-sectional study investigating seroprevalence, risk factors and livestock owner's knowledge, attitudes and practices (KAPs). BMC Public Health, 11:341.
Hosein, H.I. and El-kholy, A.M. (1993): Studies on Bovine Brucellosis in middle Egypt. Symposium on food pollution, 15-16 Nov., 1993, Assuit Univ.

Ibrahim, A.K.; Abdelall, A.A. and Amin, A.S. (2012): Long term diagnostic studies for detection of Brucella spp. in milk samples. Global Veterinaria. 8,(1): 54-61.

Ibrahim, A.K.; Ibrahim, I.G.A.; Ghoneim, M.A. and Awad, W.S. (2002): Evaluation of Polymerase Chain Reaction (PCR) and conventional Brucellosis diagnostic techniques in milk samples from different animal species. J. Egypt. Vet. Med. Assoc., 62(2): 119-131.

Ior, D.D. and Chukwu, C.C. (2015): Prevalence of Brucella antibodies in marketed cow milk in Benue state, Nigeria. African Journal of Microbiology Research; 9(28): 1752-1757.

Kadry, M.B. (1996): some studies on brucellosis in cattle and buffaloes. M.V.Sc. Thesis. Fac. Vet. Med., Cairo univ., Egypt.

Kang'ethe, E.K.; Arimi, S.M.; Omore, A.O.; McDermott, J.J.; Nduhiu, J.G.; Macharia, J.K. and Githua, A. (2004): Testing for Antibodies to Brucella abortus in Milk From Consumers and Market Agents in Kenya Using Milk Ring Test and Enzyme Immunoassay. The Kenya Veterinarian, 27: $18-21$.

Meshref, A.M.S. (2000): Brucella infection in milk and some dairy products. M.V.Sc. Thesis, Fac. Vet. Med., Beni-Seuf, Cairo Univ., Egypt.

Miller, R.; Nakavuma, J.L.; Ssajjakambwe, P.S.; Vudriko, P.; Musisi, N. and Kaneene, J.B. (2015): The Prevalence of Brucellosis in Cattle, Goats and Humans in Rural Uganda: A Comparative Study. Transbound Emerg Dis. 2016 Dec; 63(6): e197-e210.

Moawad, A.A.; Nada, H.S. and Elwanees, S.A. (2013): Assessment of some diagnostic tests for animal brucellosis. Kaferlsheikh Vet. Med. J. 11 (2), 299-316.

Mohamed, H.S.A. (1989): Studies on brucellosis in farm animals at Assiut Province with special reference to different methods of diagnosis.. Ph.D. Thesis, Fac. Vet. Med., Assiut Univ. Egypt.

Molina-Flores, B. (2010): Field experience with the control of Brucella melitensis from selected countries. In: Brucella melitensis in Eurasia and The Middle East, FAO 2010, (10): 9.

Montasser, A.M.; Hamoda, F.K. and Talaat, A.Sh. (2002): Some epidemiological and diagnostic studies on brucellosis among Ruminants in Kafer-El-Shiekh governorate. J. Egypt. Vet. Med. Assoc. 62 No.6a:25-38.

Morgan, B.W.J.; Mackinnon, D.J.; Gill, K.P.; Cowser, S.G.M. and Norris, P.I.W. (1978): Standard laboratory techniques for the 
diagnosis of brucellosis. Report series No.I, Weybridges, Cent. Vet. Lab., England.

Nicoletti, P. (1990): Vaccination against Brucella. Advanced Biotechnological Processes, 13:147-168.

Omran, E.M.M. (2007): Epidemiological studies on Brucellosis in farm animal as a source of infection to man in new valley Governorate. M.V.Sc. Thesis Fac. Vet. Med. Assuit Univ. Egypt.

Oraby, N.H.M.; Hussein A.A.; Ismail, A.A.; Elias, A.H. and Abdel Kader, H.A. (2007): The use of ELISA for diagnosis and Epidemiology of Brucella infection in some farm animals in Assuit Governorate. Vet. Med. J. Infect. Dis., 4(1): 55-56.

Plommet, M.; Fensterbank, R.; Vassal, L.; Auclair, J. and Mocquot, G. (1988): Survival of Brucellaabortus in ripened soft cheese made from naturally infected cow's milk. Le Lait 68: $115-20$.

Refai, M. (2002): Incidence and control of brucellosis in the Near East region. J. Vet. Mic. 2002, 90(1-4):81-110.

Salem, A.A.; El-Gibaly, S.M.; Hassan, M.S. and Hosein, H.I. (1987): Sensitivity of some diagnostic procedures for Brucellosis in Cattle. Assuit Vet. Med. J., 18:36, 159-163.

Samaha, H.; Al-Rowaily, M.; Khoudair, R.M. and Ashour, H.M. (2007): Prevalence of Brucella spp. in milk or tissues of animals, Multicenter Study of Brucellosis in Egypt. (2007). Emerg Infect Dis. 2008 Dec; 14(12): 1916-1918.

Schelling, E.; Diguimbaye, C.; Daoud, S.; Nicolet, J.; Boerlin, P.; Tanner, M. and Zinsstag, J.
(2003): Brucellosis and Q-fever seroprevalences of nomadic pastoralists and their livestock in Chad, Prev. Vet. Med. 61 (2003) 279-293.

Shafee, M.; Rabbani, M.; Sheikh, A.A.; Ahmad, M. and Abdul Razzaq. (2011): Prevalence of Bovine Brucellosis in Organized Dairy Farms, Using Milk ELISA, in Quetta City, Balochistan, Pakistan. Veterinary Medicine, Article ID 358950, 3 pages.

Shalaby, M.N.; Ghobashy, H.M.; El-Bauomy, E.M. and Saleh, W.M. (2003): Prevalence of brucellosis among farm animal species in some governorates in Egypt. In: proceeding of the $7^{\text {th }}$ Scientific Congress, Egyptian Society for Cattle Diseases. Assuit, Egypt., pp.271282.

Shehata, A.A. (2004): Serological Studies onmilk for diagnosis of Brucella infection in Assuit governorate. M.V.Sc. Thesis, Fac.Vet. Med., Assuit Univ., Egypt.

Thakur, S.D.; Kumar, R. and Thapliyal, D.C. (2002): Human Brucellosis: review of an underdiagnosed animal transmitted disease. J. Commun. Dis. 34 (2002) 287-301.

Zahran, E.M. (2004): Bacteriological and serological studies on brucella microorganisms in farm animals in El-Minia governorate. Ph.D Thesis, Fac. Vet.Med., Beni-Seuf, Cairo Univ., Egypt.

Zowghi, E.; Ebadi, A. and Mohseni, B. (1990): Isolation of Brucella organisms from the milk of sero-negative cows. Revue scientifiqueet technique (OIE). 9, 1175-1178.

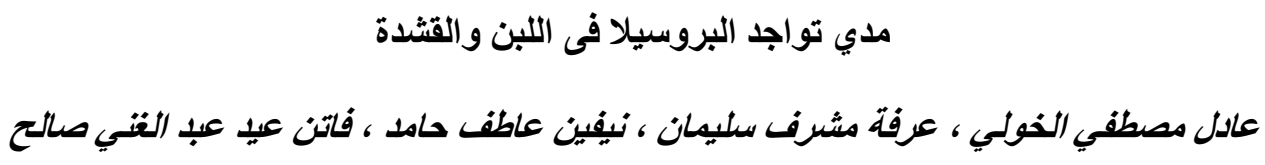

Email: fateneid2290@gmail.com_Assiut University web-site: www.aun.edu.eg

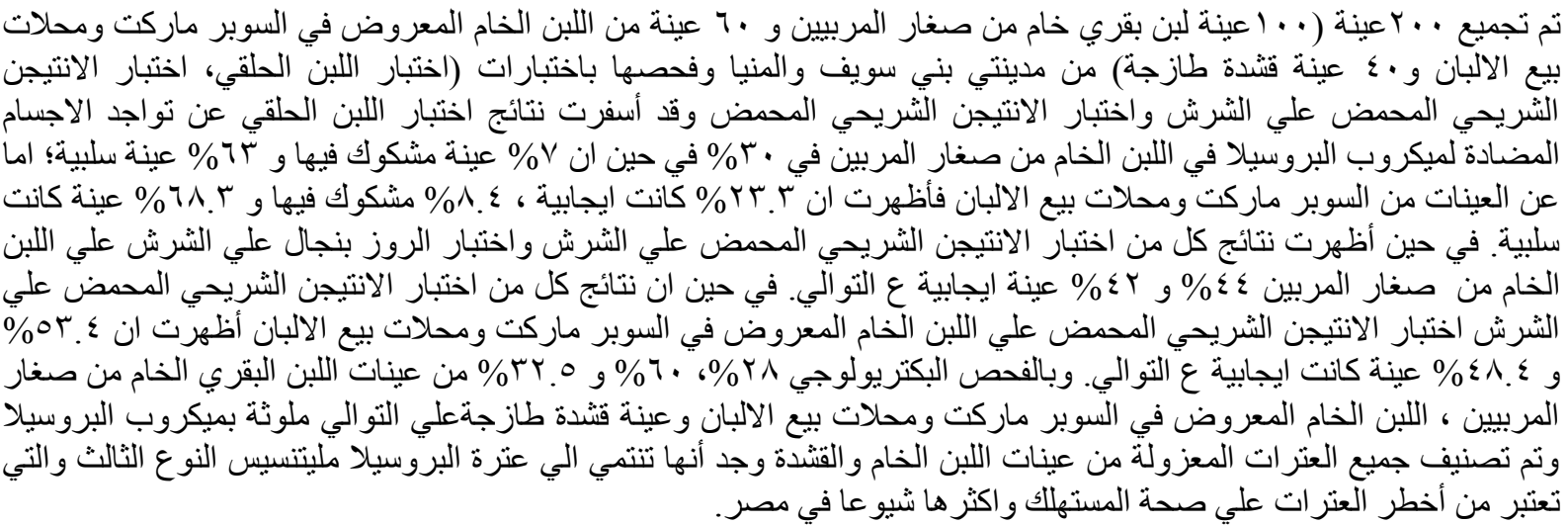

